\title{
Hydrocele Rupture during Sexual Intercourse: a Case Report and Review of the Literature
}

\section{Cinsel Illişki Esnasında Hidrosel Rüptürü: Bir Olgu Sunumu ve Literatürün Gözden Geçirilmesi}

\author{
id Deniz Bolat ${ }^{1}$, id Anıl Eker ${ }^{1}$, 'iD, Hamza Eren Güzel2, id Tansu Değirmenci ${ }^{1}$ \\ 1 University of Health Sciences Turkiye, Izmir Bozyaka Training and Research Hospital, Clinic of Urology, Izmir, Turkiye \\ 2 University of Health Sciences Turkiye, Izmir Bozyaka Training and Research Hospital, Clinic of Radiology, Izmir, Turkiye
}

\begin{abstract}
Hydrocele rupture is a rarely seen situation in clinical practice. Due to the limited number of cases in the literature, management of hydrocele rupture is controversial. A 34-year-old male patient with a history of untreated idiopathic 10x9 cm right hydrocele for one year was admitted to the emergency department with the complaints of right hemiscrotal pain and ecchymosis after a sexual intercourse. In this paper, we present our approach to a patient with hydrocele rupture developing during sexual intercourse.
\end{abstract}

Keywords: Hydrocele, Rupture, Sexual intercourse, Scrotum, Blunt trauma

Öz

Hidrosel rüptürü klinik pratikte nadir görülen bir durumdur. Literatürde bildirilen hasta sayısının azlığından dolayı bu hastaların yönetimi tartışmalıdır. Bir yıldır tedavi edilememiş idiyopatik 10x9 cm'lik hidrosel öyküsü olan 34 yaşındaki bir erkek hasta acil servise cinsel ilişkiden sonra başlayan sağ hemiskrotumda ağrı ve ekimoz şikayeti ile başvurdu. Burada cinsel ilişki sırasında hidrosel rüptürü gelişen bir hastaya kendi yaklaşımımızı sunduk.

Anahtar Kelimeler: Hidrosel, Rüptür, Cinsel ilişki, Skrotum, Künt travma

\section{Introduction}

Hydrocele is an abnormal collection of fluid between the visceral and parietal layers of the tunica vaginalis (1). Although hydrocele is a very common situation that causes scrotal mass and pain in men, rupture of a hydrocele is an unusual condition in routine clinical practice. Less than ten cases have been reported in the current literature. In these cases, the etiologies of the rupture were sexual intercourse, trauma, long-term steroid exposure and idiopathic $(2,3,4,5,6)$. Due to the limited number of reported cases, management of hydrocele is controversial. In this case, we present our approach to a 34-year-old man with hydrocele rupture occurring during sexual intercourse.

\section{Case Presentation}

A 34-year-old male patient admitted to the emergency department with the complaint of right hemiscrotal pain. His complaint started 2 hours ago during sexual intercourse after a cracking sound heard from his scrotum. According to the patient's history, the patient was awake; his partner was on the top position and the scrotum was exposed to blunt trauma while the partner was sitting on.

He had a history of right hemiscrotal gross hydrocele which occurred one year ago without any etiological factor such as epididymo-orchitis, testicular torsion, blunt or penetrating scrotal trauma, scrotal or inguinal surgery or pelvic radiotherapy (Figure 1a). The size of the right hydrocele sac was found to be

Correspondence: Deniz Bolat MD, University of Health Sciences Turkiye, İzmir Bozyaka Training and Research Hospital, Clinic of Urology, İzmir, Türkiye Phone: +90 5056383010 E-mail: drbolat@hotmail.com ORCID-ID: orcid.org/0000-0001-7338-8737

Received: 21.08 .2019 Accepted: 02.12.2019

Cite this article as: Bolat D, Eker A, Aydın ME, Değirmenci T. Hydrocele Rupture During Sexual Intercourse: a Case Report and Review of the Literature. J Urol Surg 2020;7(2):149-151.

๑Copyright 2020 by the Association of Urological Surgery / Journal of Urological Surgery published by Galenos Publishing House. 
$10 \times 9 \mathrm{~cm}$ and the volume and shape of the testes were within the normal range (Figure 1b). The hydrocele sac was found to have no communication with the peritoneum and diagnosed as idiopathic hydrocele. At that time, hydrocelectomy was planned, but the patient refused surgery. Moreover, despite progressive growing of the hydrocele sac, he did not visit any hospital during the last six months.

Physical examination was compatible with decompressed hydrocele and pain during palpation on the right side with normal sized and shaped testes. Scrotal Doppler ultrasonography (USG) demonstrated rupture of the parietal layer of the tunica vaginalis and reduced hydrocele liquid. The ruptured tunica vaginalis layer caused fluid septation and there was accumulation of fluid between the scrotal layers. The size and shape of both testes and epididymis were normal (Figure 1c). Hematological
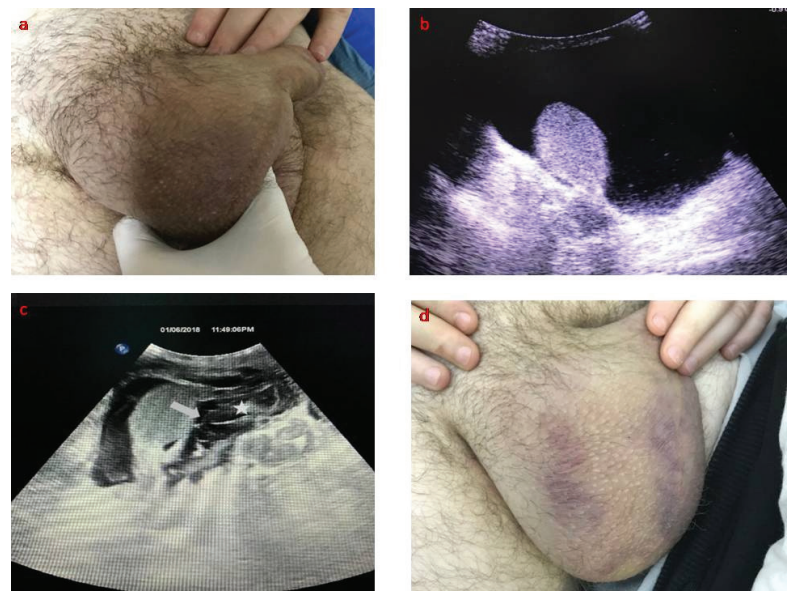

Figure 1. Images of hydrocele rupture before and after sexual intercourse. a) Pre-incident ultrasound view of the hydrocele sac and the testis. b) Acute view of hydrocele rupture. c) Ultrasound view of hydrocele rupture. Rupture of the parietal layer of tunica vaginalis (arrow) and collection of hydrocele liquid between scrotal layers were demonstrated (star). d) $3^{\text {rd }}$ day of follow up: ecchymoses appeared and biochemical parameters were within the normal limits. The diagnosis was a ruptured right scrotal hydrocele.

Conservative treatment was started with scrotal elevation and cold compresses; in addition, daily diclofenac sodium $75 \mathrm{mg}$ and ceftriaxone $1 \mathrm{~g}$ intramuscular twice a day were applied. Scrotal swelling was reduced and ecchymoses appeared. At the end of the 3rd day of admission, the patient was discharged without any surgical procedure (Figure 1d). After one week, scrotal USG revealed a decrease in the volume of the fluid. At the $3 \mathrm{rd}$ month and 1 year follow-ups, no fluid collection or hydrocele formation was observed.

Eighteen months later, the patient was admitted with recurrence of swelling of the right hemiscrotum. Physical examination and scrotal USG were performed and hydrocele of the same size was observed (Figure 2) and delayed hydrocelectomy was performed.

\section{Discussion}

Hydrocele can be congenital or acquired. Congenital hydrocele is associated with a patent processus vaginalis and consequent communication between the tunica vaginalis and the peritoneal cavity. Acquired hydrocele may occur as a reaction to tumor
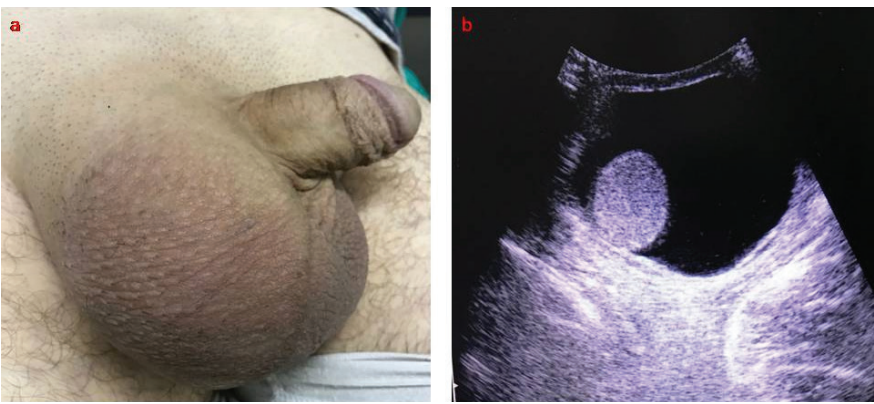

Figure 2. Images of relapsed hydrocele a) Recurrence of hydrocele after eighteen months, b) Hydrocele recurrence in ultrasonography

Table 1. Causes and treatment options of previous reported cases in the literature

\begin{tabular}{|l|l|l|l|l|}
\hline Reference & Year & Cause & Treatment & History/Presentation \\
\hline Flores et al. (3) & 2015 & $\begin{array}{l}\text { Blunt trauma } \\
\text { (Sexual intercourse) }\end{array}$ & Conservative treatment & $\begin{array}{l}\text { Twenty eight years old patient with 2-year history of right } \\
\text { hydrocele (14.1x8.9 cm) / Acute scrotal pain during sexual } \\
\text { intercourse. }\end{array}$ \\
\hline Wiwanitkit et al. (6) & 2011 & $\begin{array}{l}\text { Blunt trauma } \\
\text { (Work accident) }\end{array}$ & Conservative treatment & $\begin{array}{l}\text { Twenty four year old patient with 4-year history of right } \\
\text { hydrocele / accidental crush by a big box at work and sudden } \\
\text { pain with mass in scrotum }\end{array}$ \\
\hline Farina et al. (4) & 2002 & Idiopathic & $\begin{array}{l}\text { Conservative treatment } \\
\text { / late surgery because } \\
\text { of recurrence }\end{array}$ & $\begin{array}{l}\text { Twenty six years old patient with 5-year history of left medium } \\
\text { size hydrocele / acute scrotal pain and swelling whilst as sleep. }\end{array}$ \\
\hline Quint et al. (5) & 1992 & $\begin{array}{l}\text { Chronic steroid } \\
\text { use }\end{array}$ & $\begin{array}{l}\text { Conservative treatment } \\
\text { / late surgery because } \\
\text { of recurrence }\end{array}$ & $\begin{array}{l}\text { Sixty nine years old patientwith 15-year history of hydrocele } \\
\text { (15 cm) / acute scrotal pain and swelling after rolling over in his } \\
\text { sleep }\end{array}$ \\
\hline Wolf et al. (9) & 1955 & Idiopathic & $\begin{array}{l}\text { Early surgery } \\
\text { Sixty two years old patient with 3-year history of right hydrocele } \\
\text { / scrotal discomfort and discoloration extending into the penis. }\end{array}$ \\
\hline Senger et al. (8) & 1946 & Blunt trauma & Early surgery & \\
\hline
\end{tabular}


infection or trauma. However, they are most commonly idiopathic. The main pathophysiology of the hydrocele formation is excessive fluid production or absorption defect from the layers of the tunica vaginalis. Hydrocele represents the most common cause of painless scrotal swelling $(1,3)$. Physical examination and USG are used for hydrocele diagnosis. On USG, hydrocele appears as anechoic fluid collection surrounding the testis (7). On physical examination, there is a painless and nonecchymotic scrotal mass. Ipsilateral testicle usually cannot be palpated because of hydrocele. Hydroceles are typically managed by an open surgical procedure known as hydrocelectomy. Another option is needle aspiration but this method has higher recurrence risk (1).

Spontaneous hydrocele rupture is a rare condition with less than 10 reported cases in the literature. If the reasons are examined, we can see that the common cause is trauma $(2,3,4,5,6)$. In one case, the patient reported that he had got accidentally crush with a big box during his daily work; in another case, rupture occurred while the patient was stepping on to a chair which slipped from under him and struck him in the scrotum $(6,8)$ Sexual trauma has been shown in only one case (3). Other reasons are spontaneous rupture during sleeping, long-term exogenous steroid use and idiopathic $(2,3,9)$.

Only in early 1900s, cases were treated with early surgery in the acute phase which means emergency hydrocelectomy at the initial admission (10). It may be related to miss-diagnosis because of the absence of imaging techniques and patient complaints. In recent reports, conservative approach was applied in most of the cases and treated successfully $(3,6)$. A late surgery was required for some of the patients who were treated with conservative treatment because of recurrence of hydrocele $(4,5)$ (Table 1). In acute phase, one patient was expectantly managed with antiinflammatory and pain medication, and was instructed to wear a scrotal support for 2 weeks to help relieve discomfort. Another patient was managed with oral anti-inflammatory agents, analgesics and prophylactic antibiotics, combined with bed rest and scrotal elevation. Surgery was recommended for one patient but he refused. The contents of conservative treatment were not specified in that case. There is no consensus on which anti-inflammatory drug should be used or which antibiotics should be given to the patient $(3,4,6)$.

In conservative treatment, non-steroidal anti-inflammatory drugs were used and scrotal elevation was performed to this patient. Four of the patients were treated successfully with conservative treatment in two weeks $(2,3,5,6)$. A delayed surgery was performed because of recurrence of hydrocele in one patient (3). In this case, the patient was successfully treated conservatively in one week, but, hydrocele recurred eighteen months later and a delayed surgery was performed.

\section{Ethics}

Informed Consent: Written informed consent was obtained from the parents before publication of this paper.

Peer-review: Externally and internally peer-reviewed.

\section{Authorship Contributions}

Surgical and Medical Practices: D.B., A.E., H.E.G., Concept: D.B., A.E., Design: D.B., A.E., Data Collection or Processing: A.E., H.E.G., T.D., Analysis or Interpretation: D.B., A.E., H.E.G., T.D., Literature Search: A.E., H.E.G., Writing: D.B., A.E.

Conflict of Interest: No conflict of interest was declared by the authors.

Financial Disclosure: The authors declared that this study received no financial support.

\section{References}

1. Rubenstein RA, Dogra VS, Seftel $A D$, Resnick MI. Benign intrascrotal lesions. J Urol 2004;171:1765-1772.

2. Cuervo Pinna C, Rodriguez Rincón JP, Garcia-Moreno AA, Cabello Padial J, Murillo Mirat J, Fernández de Alarcón L. [Spontaneous rupture of hydrocele: an unusual complication]. Actas Urol Esp 1998;22:610-612.

3. Flores VX, Wallen JJ, Martinez DR, Carrion R. Deflate-gate: Conservative Management of a Large Ruptured Hydrocele. Urol Case Rep 2015;3:198200.

4. Fariña LA, Quintana JL, Zungri ER. Acute rupture of hydrocele. Braz J Urol 2002; 28:45-46.

5. Quint HJ, Miller JI, Drach GW. Rupture of a hydrocele: an unusual event. J Urol 1992;147:1375-1377.

6. Wiwanitkit V. Accidental rupture of hydrocele: a case report. Urol J $2011 ; 8: 163-164$.

7. Patil V, Shetty SM, Das S. Common and Uncommon Presentation of Fluid within the Scrotal Spaces. Ultrasound Int Open 2015;1:E34-40.

8. Senger FL, Bottone JJ, Murray GE. Traumatic rupture of a hydrocele sac. Am J Surg 1946;72:608.

9. Wolf M, Gomila FR. Spontaneous rupture of a hydrocele testis. Am J Surg 1955;89:703-704

10. Collins JD. Traumatic Rupture of the Tunica Vaginalis in Hydroceles. South Med Jour. 1930;23:247-250. 